\title{
PENGADAAN TANAH UNTUK KEPENTINGAN UMUM YANG MELIBATKAN PIHAK SWASTA PERSPEKTIF HUKUM ISLAM
}

\author{
Muwahid \\ Universitas Islam Negeri Sunan Ampel Surabaya | Jl. A. Yani I 17 Surabaya \\ muwahidizza@gmail.com
}

\begin{abstract}
There has been changes in the issue of land procurement for national development and public use in Indonesia. The article highlights the role of private sector in the process. While in some previous regulation private are not involved in the process, the Law No. I |/2012 states that private sectors can involve in innfrastructure construction for public facilities, whereas the procurement of land for the purpose is conducted by the govenrment. This has been in line with islamic law of property in which revocation of individual's propety, including land propert, by the state and its use for public goods is allowed. In so doing, the government should do the procurement, not private sectors.
\end{abstract}

Keywords: revocation and procurement of land, public welfare, private

Abstrak: Dinamika pengaturan pengadaan tanah bagi pembangunan untuk kepentingan umum yang melibatkan swasta adalah bahwa dalam Peraturan Menteri Dalam Negeri Nomor I5 Tahun 1975, swasta terlibat penuh dalam pengadaan tanah, sementara dalam Keputusan Presiden Nomor 55 Tahun 1993, Peraturan Presiden Nomor 36 Tahun 2005, dan Peraturan Presiden Nomor 65 Tahun 2006, swasta tidak dapat terlibat dalam pengadaan tanah, sementara dalam UU. Nomor 2 Tahun 2012, swasta dapat terlibat dalam pelaksanaan pembangunan untuk kepentingan umum, sementara pengadaan tanahnya domain pemerintah. Formulasi pengaturan keterlibatan pihak swasta dalam pengadaan tanah bagi pembangunan untuk kepentingan umum, yaitu melalui model kerjasama pemerintah swasta (Public Privat Partnership), di mana pemerintah melakukan pengadaan tanah sedangkan swasta melaksanakan pembangunan infrastrukturnya. Dalam perspektif hukum Islam, pembebasan dan pencabutan hak atas tanah diperbolehkan apabila peruntukannya untuk kepentingan umum, 
bukan untuk kepentingan komersil, dan yang harus melakukan pembebasan atau pencabutan adalah pemerintah, bukan pihak swasta. Kata Kunci: Pengadaan tanah, kepentingan umum, swasta, hukum Islam.

\section{Pendahuluan}

Masalah tanah dalam pembangunan merupakan suatu permasalahan yang cukup peka. Dengan meningkatnya pembangunan, kebutuhan tanah untuk pembangunan tersebut semakin bertambah pula. Tanah bukan saja mengandung aspek ekonomi akan tetapi juga menyangkut masalah sosial, politik, hukum dan sebagainya. ${ }^{1}$ Atas dasar itu, kebutuhan tanah untuk pembangunan bukan merupakan suatu hal yang mudah, akan tetapi merupakan masalah yang cukup berat, sebab apabila keliru memecahkannya akan menimbulkan keresahan yang mengganggu stabilitas masyarakat. ${ }^{2}$

Pengadaan tanah bagi pelaksanaan pembangunan dilakukan oleh pemerintah untuk kepentingan umum, menurut ketentuan Undang-Undang Nomor 2 Tahun 2012 tentang Pengadaan Tanah bagi Pembangunan untuk Kepentingan Umum (LN.2012-22.TLN. 5280), pasal 1 ayat (6) menentukan "kepentingan umum adalah kepentingan bangsa, negara, dan masyarakat yang harus diwujudkan oleh pemerintah dan digunakan sebesar-besarnya untuk kemakmuran rakyat".

Definisi yang diberikan oleh pasal 1 ayat 6 Undang-Undang Nomor 2 Tahun 2012 di atas masih merupakan definisi yang kabur (vage normen). ${ }^{3}$ Dalam undang-undang tersebut hanya disebutkan secara enumeratif kegiatan-kegiatan pembangunan untuk kepentingan umum, tanpa memberikan batasan yang jelas, sehingga dalam pelaksanaannya terjadi perbedaan penafsiran

\footnotetext{
Adrian Sutedi, Implementasi Prinsip Kepentingan Umum dalam Pengadaan Tanah untuk Pembangunan, (Jakarta: Sinar Grafika, 2008), 45.

${ }^{2}$ Ibid., 46.

3 Jj. Bruggink, Rechtsrefleties, Alih Bahasa: Arif Sidharta, (Bandung: PT. Citra Aditya Bakti, 1999), 6 I.

${ }^{4}$ Yusriadi, Industrialisasi \& Perubahan Fungsi Sosial Hak Milik atas Tanah, (Yogyakarta: Genta Publising, 20I0), 38.
} 
mengenai apa yang disebut sebagai kepentingan umum. ${ }^{4}$ Secara filsafati, pengadaan tanah bagi pembangunan diorientasikan untuk mewujudkan kemakmuran dan kesejahteraan rakyat, bukan untuk mencari keuntungan (non profit oriented). Untuk mencapai kemakmuran dan kesejahteraan rakyat, pengadaan tanah dan pelaksanaan pembangunan untuk kepentingan umum harus dilakukan oleh pemerintah, bukan dilakukan swasta.

Hal ini bertolak belakang dengan ketentuan pasal 12 ayat (1) Undang-Undang Nomor 2 Tahun 2012 yang memberikan peluang kepada pemerintah untuk bekerja sama dengan pihak swasta dalam pelaksanaan pembangunan untuk kepentingan umum. Secara yuridis, ketentuan dalam pasal 12 ayat (1) tersebut merupakan norma yang kabur (vage norm), kekaburan norma tersebut dapat dilihat dalam rumusan norma "Pembangunan untuk kepentingan umum sebagaimana dimaksud dalam pasal 10 huruf $\mathrm{b}$ sampai huruf $\mathrm{r}$ wajib diselenggaraan Pemerintah dan dapat bekerjasama dengan Badan Usaha Milik Negara, Badan Hukum Milik Daerah, atau Badan Usaha Swasta". Dalam pasal 12 ayat (1) maupun dalam penjelasan pasal tersebut tidak ada batasan mengenai bentuk dan sifat kerja sama antara pemerintah dengan badan usaha swasta. Hal ini dapat membuka peluang kegiatan pembangunan untuk kepentingan umum yang pada awalnya dimiliki dan dilaksanakan oleh pemerintah akan berubah menjadi milik swasta yang berorientasi pada keuntungan (profit oriented).

Berdasarkan hal di atas, maka artikel ini membahas tentang dinamika pengaturan pengadaan tanah yang melibatkan swasta, dan menjelaskan formulasi pengaturan pengadaan tanah bagi pembangunan untuk kepentingan umum yang melibatkan badan usaha swasta. 


\section{Dinamika Pengaturan Pengadaan Tanah bagi Pembangunan untuk Kepentingan Umum yang Melibatkan Swasta}

Terdapat beberapa peraturan tentang pengadaan tanah bagi pembangunan untuk kepentingan umum yang melibatkan swasta yaitu; Peraturan Menteri Dalam Negeri Nomor 15 Tahun 1975 tentang Ketentuan-Ketentuan mengenai Tata Cara Pembebasan Tanah, Keputusan Presiden Nomor 55 Tahun 1993 tentang Pengadaan Tanah bagi Pelaksanaan Pembangunan untuk Kepentingan Umum, Peraturan Presiden Republik Indonesia Nomor 65 Tahun 2006 tentang Perubahan atas Peraturan Presiden Nomor 36 Tahun 2005 tentang Pengadaan Tanah bagi Pelaksanaan Pembangunan untuk Kepentingan Umum, dan undang-undang Nomor 2 Tahun 2012 tentang Pengadaan Tanah bagi Pembangunan untuk Kepentingan Umum.

\section{Peraturan Menteri Dalam Negeri Nomor 15 Tahun 1975 tentang Ketentuan-Ketentuan mengenai Tata Cara Pembebasan Tanah}

Istilah pengadaan tanah tidak dikenal dalam Peraturan Menteri Dalam Negeri Nomor 15 Tahun 1975, istilah yang dipakai oleh PMDN Nomor 15 Tahun 1975 adalah pembebasan tanah yang diartikan; "melepaskan hubungan hukum antara pemegang hak atas tanah dengan tanah yang dikuasainya dengan memberikan ganti rugi yang layak". Dalam PMDN Nomor 15 Tahun 1975, tidak terlihat ada terminologi kepentingan umum, hanya dalam konsideran menimbang disebutkan akan tanah dalam usaha-usaha pembangunan yang dilakukan oleh instansi pemerintah, dalam hal ini kepentingan umum adalah kepentingan pembangunan yang dilaksanakan oleh pemerintah. Selain tidak ada pengertian yang tegas mengenai kepentingan umum, juga tidak ada daftar-daftar kegiatan yang dikatagorikan dalam kepentingan umum tersebut, sehingga dengan pengaburan arti dari kepentingan umum dengan hanya menyebut kepentingan pembangunan, maka dari pijakan inilah salah satu kemungkinan dapat terjadi penyimpangan kegiatan 
pembebasan tanah tersebut, sehingga dapat saja dimanipulasi kepentingan swasta disebut juga sebagai kepentingan pembangunan hanya karena ada keterlibatan pejabat pemerintah dalam melakukan pembebasan tanah.

Dalam praktik, ternyata pembebasan tanah ini cenderung disalahgunakan, baik dalam hal tujuan pembebasan maupun penetapan ganti ruginya. Tujuan pembebasan tanah yang seharusnya untuk kepentingan umum tetapi dapat disimpangi oleh pelaksana untuk kepentingan lain, juga dalam penetapan ganti rugi sering terjadi pemaksaan, sedangkan musyawarah yang dikehendaki ternyata hanya dilakukan komunikasi satu arah.

Dalam rangka mengakomodasi kepentingan swasta untuk memperoleh tanah, pemerintah kembali menerbitkan Peraturan Menteri Dalam Negeri Nomor 2 Tahun 1976 tentang Acara Pembebasan Tanah untuk Kepentingan Pemerintah bagi Pembebasan Tanah oleh Pihak Swasta. Latar belakang diterbitkannya PMDN Nomor 2 Tahun 1976 yaitu; pertama, pelaksanaan pembangunan tidak semata-mata menjadi beban pemerintah, melainkan diharapkan adanya peran aktif dari pihak swasta; kedua, untuk merangsang pihak swasta dalam pelaksanaan pembangunan dipandang perlu adanya bantuan fasilitas dari pemerintah yang berbentuk jasa-jasa dalam pembebasan tanah rakyat dalam rangka penyediaan tanah untuk proyek-proyek yang bersifat menunjang kepentingan umum atau termasuk dalam bidang pembangunan sarana umum dan fasilitas-fasilitas sosial. ${ }^{5}$

Dalam Pasal 1 dan 2 PMDN Nomor 2 Tahun 1976 ditekankan bahwa pihak swasta yang melakukan pembebasan tanah, sebelum merealisasikan proyeknya harus mendapat izin tertulis dari Gubernur, yang mencantumkan bahwa pembebasan tanah dilakukan untuk kegiatan yang bertujuan untuk

${ }^{5}$ Gunanegara, “Pengadaan Tanah Oleh Negara Untuk Kepentingan Umum”, Disertasi, (Surabaya: Program Pascasarjana Universitas Airlangga, 2006), 157. 
pembangunan yang bersifat menunjang kepentingan umum atau termasuk bidang pembangunan sarana umum, dan fasilitas sosial. Surat izin pembebasan tanah oleh swasta tersebut harus mencantumkan alasan-alasan dan pertimbangan-pertimbangan yang digunakan oleh Gubernur untuk memberikan izin, untuk itu Gubernur berkewajiban melakukan pengawasan atas pelaksanaan pembebasan tanah. ${ }^{6} \mathrm{Di}$ samping itu, berdasarkan ketentuan pasal 11 PMDN Nomor 15 Tahun 1975 pemerintah daerah setempat berkewajiban mengawasi pelaksanaan pembebasan tanah dan pemberian ganti rugi dalam pelaksanaan pembebasan tanah untuk kepentingan swasta.

Dalam PMDN Nomor 2 Tahun 1976 tidak ada kriteria dan syarat-syarat yang harus dipenuhi untuk masuk dalam kualifikasi kepentingan umum, sehingga dalam praktik penggunaan PMDN Nomor 2 Tahun 1976 lebih banyak menimbulkan permasalahan hukum bagi pemilik tanah. Penyimpangan pengadaan tanah untuk kepentingan umum yang dilakukan oleh swasta yang semula diijinkan hanya untuk tujuan yang menunjang kepentingan umum, atau pembangunan sarana umum/fasilitas sosial sebagaimana diatur dalam PMDN Nomor 2 Tahun 1976 ternyata oleh Menteri Dalam Negeri diizinkan menggunakan lembaga pembebasan tanah untuk kepentingan proyek swasta sebagaimana yang dimuat dalam Surat Edaran Nomor SJ 16/10/41 tanggal 19 Oktober 1976.7

Dengan ketentuan dari Peraturan Menteri Dalam Negeri Nomor 2 Tahun 1976 di atas, pemerintah dan swasta dapat memaksa masyarakat untuk melepaskan hak atas tanahnya dengan mengatasnamakan pembangunan. Peraturan ini tidak hanya mengatur perolehan tanah untuk kepentingan pemerintah, tetapi juga memberikan peluang yang longgar kepada swasta untuk memperoleh tanah sebagaimana 
perolehan tanah untuk kepentingan pembangunan. ${ }^{8}$ Bahkan dalam praktik tidak jarang terjadi intervensi pemerintah melalui kepanitiaan pembebasan tanah, yakni diperbolehkannya swasta menggunakan acara pembebasan tanah yang sama dengan yang dilakukan oleh pemerintah, juga tidak segan-segan menggunakan aparat pemerintah dan aparat keamanan dalam pembebasan tanah untuk kepentingan pembangunan, sehingga pihak swasta dapat memperoleh tanah dengan harga di bawah rata-rata sebagaimana ditetapkan oleh panitia pembebasan tanah. ${ }^{9}$

2. Keputusan Presiden Nomor 55 Tahun 1993 tentang Pengadaan Tanah bagi Pelaksanaan Pembangunan untuk Kepentingan Umum

Pengaturan pengadaan tanah bagi pembangunan untuk kepentingan umum sebagaimana diatur dalam PMDN Nomor 15 Tahun 1975 dalam kenyataannya tidak sesuai dengan keadaan dan perkembangan jaman. Oleh karena itu pemerintah mengeluarkan Keputusan Presiden Nomor 55 Tahun 1993 tentang Pengadaan Tanah bagi Pelaksanaan Pembangunan untuk Kepentingan Umum. Perubahan instrumen hukum tersebut disebabkan karena pelaksanaan pembebasan tanah, baik yang menyangkut pengadaan tanah bagi pembangunan untuk kepentingan umum maupun pembebasan tanah untuk kepentingan swasta, selalu menimbulkan disharmoni. Penyebab semua permasalahan pembebasan tanah atau pengadaan tanah adalah karena faktor peraturannya, penyimpangan oleh pelaksanaannya, atau ekses dari penerapan peraturannya. ${ }^{10}$

Istilah pembebasan tanah dalam PMDN Nomor 15 Tahun 1975 diganti dengan istilah pengadaan tanah dalam Keputusan Presiden Nomor 55 Tahun 1993, oleh karena dalam pelaksanaan

\footnotetext{
8 Muhammad Yamin \& Abdul Rahim Lubis, Pencabutan Hak, Pembebasan, dan Pengadaan Tanah, (Bandung: Mandar Maju, 20II), 17.

9 Ibid., 19.

${ }^{10}$ Gunanegara, Pengadaan Tanah..., 160.
} 
pembebasan tanah mendapat respon yang kurang positif dari masyarakat, sehubungan dengan banyaknya permasalahanpermasalahan yang ditimbulkan dalam pembebasan tanah, sekaligus untuk menampung aspirasi berbagai kalangan dalam masyarakat sebagai reaksi terhadap ekses-ekses pembebasan tanah yang selama ini dilakukan. ${ }^{11}$

Dengan berlakunya Keppres Nomor 55 Tahun 1993 ini secara tegas dinyatakan PMDN Nomor 15 Tahun 1975 tidak berlaku, namun demikian ketentuan dalam Keppres Nomor 55 Tahun 1993 tersebut dirasakan belum operasional, sehingga dalam pasal 25 ditentukan bahwa ketentuan lebih lanjut yang diperlukan bagi pelaksanaan Keputusan Presiden ini dilakukan oleh Menteri Negara Agraria/Kepala Badan Pertanahan Nasional. Untuk memenuhi ketentuan pasal 25 tersebut diterbitkan aturan operasional dari pengadaan tanah yang dimaksud dengan Peraturan Menteri Negara Agraria/Kepala Badan Pertanahan Nasional Nomor 1 Tahun 1994 tentang Ketentuan Pelaksanaan Keputusan Presiden Nomor 55 Tahun 1993 tentang Pengadaan tanah bagi Pelaksanaan pembangunan untuk kepentingan umum. ${ }^{12}$

Pasal 1 butir 1 Keppres Nomor 55 Tahun 1993 menyatakan bahwa yang dimaksud dengan pengadaan tanah adalah setiap kegiatan untuk mendapatkan tanah dengan cara memberikan ganti kerugian kepada yang berhak atas tanah. Berdasarkan rumusan itu, dapat diketahui bahwa istilah pengadaan tanah lahir karena keterbatasan persediaan tanah untuk pembangunan, sehingga untuk memperolehnya perlu dilakukan dengan memberikan ganti kerugian kepada yang berhak. Dalam konsideran Keppres Nomor 55 Tahun 1993 disebutkan bahwa pelaksanaan pengadaan tanah dilakukan dengan memperhatikan peran tanah dalam kehidupan manusia

" Maria SW Soemardjono, Kebijakan Pertanahan Antara Regulasi dan Implementasi, (Jakarta: Penerbit Buku Kompas, 2005), 72.

12 Muhammad Yamin \& Abdul Rahim Lubis, Pencabutan Hak, 54. 
dan prinsip penghormatan terhadap hak-hak yang sah atas tanah. ${ }^{13} \mathrm{Hal}$ itu berarti, dalam pengadaan tanah di satu pihak harus diingat fungsi sosial atas tanah, namun di lain pihak, kepentingan pihak yang memiliki hubungan hukum dengan tanah tersebut harus tetap dihormati.

Menurut Keppres Nomor 55 Tahun 1993, pengadaan tanah bagi pembangunan untuk kepentingan umum hanya dapat dilakukan oleh pemerintah, pihak swasta tidak dapat dilibatkan di dalamnya. Ketentuan dalam Keppres ini berbeda dengan ketentuan sebelumnya (PMDN Nomor 15 Tahun 1975) yang memberikan peluang kepada swasta untuk melaksanakan pengadaan tanah bagi pelaksanaan pembangunan untuk kepentingan umum dengan bantuan panitia pengadaan tanah yang seyogyanya merupakan fasilitas bagi pengadaan tanah yang dilakukan oleh instansi pemerintah. ${ }^{14}$ Dengan demikian, pihak swasta tidak dapat memanfaatkan Keputusan Presiden ini untuk ikut terlibat dalam pengadaan tanah.

Dalam Keppres Nomor 55 Tahun 1993 konsep kepentingan umum didefinisikan dengan jelas yaitu kepentingan seluruh lapisan masyarakat, dengan 3 kriteria, yaitu; dimiliki oleh pemerintah, dikuasai oleh pemerintah, dan tidak untuk mencari keuntungan. Dengan pembatasan-pembatasan itu, maka pihak swasta pada dasarnya tidak dapat terlibat dalam pengadaan tanah, pengadaan tanah yang dilakukan oleh swasta hanya dapat dilakukan melalui cara biasa yaitu jual beli, tukar menukar atau cara lain yang disepakati oleh para pihak.

Pelaksanaan pengadaan tanah dilakukan dengan musyawarah untuk menentukan ganti kerugian antara pemegang hak atas tanah, panitia pengadaan tanah dan instansi pemerintah yang memerlukan tanah. Ganti kerugian dalam rangka pengadaan tanah diberikan untuk; hak atas tanah;

13 Olloan Sitorus \& Dayat Limbong, Pengadaan Tanah Untuk Kepentingan Umum, (Yogyakarta: Penerbit Mitra Kebijakan Tanah Indonesia, 2004), 5.

${ }^{14} \mathrm{lbid}$. 
bangunan; tanaman; dan benda-benda lain yang berkaitan dengan tanah. Bentuk ganti kerugian dapat berupa; uang, tanah pengganti, pemukiman kembali, gabungan dari dua atau lebih bentuk ganti kerugian di atas, atau bentuk lain yang disepakati oleh pihak-pihak yang bersangkutan (pasal 12-13). Apabila pemegang hak atas tanah tidak menerima keputusan panitia pengadaan tanah mengenai bentuk dan besarnya ganti kerugian, ia dapat mengajukan keberatan kepada Gubernur, selanjutnya Gubernur akan mengupayakan penyelesaian mengenai bentuk dan besarnya ganti kerugian dengan mempertimbangkan pendapat dan keinginan para pihak. Selanjutnya Gubernur akan memutuskan mengenai bentuk dan besarnya ganti kerugian, jika pemegang hak atas tanah tetap menolak keputusan Gubernur mengenai ganti kerugian, Gubernur mengusulkan pencabutan hak atas tanah kepada Presiden. Presiden memutuskan pencabutan hak atas tanah setelah mendengar pertimbangan dari Menteri Hukum dan Hak Asasi Manusia, Menteri Dalam Negeri dan Menteri dari Instansi yang memerlukan tanah (pasal 20-21).

Keppres Nomor 55 Tahun 1993 juga mengatur mengenai kemungkinan untuk memperoleh tanah dengan cara jual beli, tukar menukar antara pemilik tanah dengan instansi pemerintah yang memerlukan tanah. ${ }^{15}$ Hal ini secara tegas dijelaskan dalam pasal 23 Keppres Nomor 55 Tahun 1993 yang menyebutkan bahwa pelaksanaan pembangunan untuk kepentingan umum yang memerlukan tanah yang luasnya kurang dari 1 (satu) hektar, dapat dilakukan secara langsung oleh instansi pemerintah yang memerlukan tanah dengan pemegang hak atas tanah dengan cara jual beli, tukar menukar atau cara lain yang disepakati. 
3. Peraturan Presiden Republik Indonesia Nomor 65 Tahun 2006 tentang Perubahan atas Peraturan Presiden Nomor 36 Tahun 2005 tentang Pengadaan Tanah bagi Pelaksanaan Pembangunan untuk Kepentingan Umum

Pengaturan pengadaan tanah dalam Keppres Nomor 55 Tahun 1993 dalam perkembangannya dinilai mengandung beberapa kelemahan. Beberapa kelemahan Keputusan Presiden Nomor 55 Tahun 1993 menurut Gunanegara yaitu:

a. Tidak mampu mengatasi percaloan (mafia) tanah yang telah ditetapkan sebagai lokasi pembangunan, akibatnya biaya pembangunan menjadi mahal bahkan pembangunan menjadi berhenti.

b. Jiwa pengaturannya masih bersifat sentralistik dan dijalankan secara otoriter yang pada kondisi sekarang ini pola pemerintahan sudah berubah ke arah desentralisasi yang dijalankan secara demokratis.

c. Pasca pembebasan banyak rakyat pemilik tanah yang terdegradasi kehidupan sosial ekonominya.

d. Struktur atau komposisi panitia pengadaan tanah yang semuanya dari pejabat pemerintah yang dalam implementasinya tidak dapat menghilangkan keberpihakan kepada negara, dibanding kepada rakyat pemilik tanah, misalnya dalam penentuan ganti rugi, terjadi pemaksaan nilai ganti rugi dengan didasarkan pada nilai pajak (NJOP), bukan didasarkan pada land value yang riil; musyawarah dijalankan tidak sebagai mestinya, tetapi diarahkan sebagai media sosialisasi atau indoktrinasi ${ }^{16}$.

Berdasarkan kelemahan-kelemahan di atas, Pemerintah mengeluarkan Peraturan Presiden Nomor 36 Tahun 2005 tentang pengadaan tanah bagi pembangunan untuk kepentingan umum. Dasar pertimbangan dikeluarkannya Peraturan Presiden Nomor 36 Tahun 2005 yaitu: pertama,

${ }^{16}$ Gunanegara, Pengadaan Tanah..., 164. 
meningkatnya pembangunan untuk kepentingan umum yang memerlukan tanah, maka pengadaannya perlu dilakukan secara cepat dan transparan dengan tetap memperhatikan prinsip penghormatan terhadap hak-hak atas tanah; kedua, pengadaan tanah bagi pembangunan untuk kepentingan umum sebagaimana ditetapkan dalam keputusan Presiden Nomor 55 Tahun 1993 dinilai tidak sesuai lagi dengan landasan hukum bagi pengadaan tanah untuk kepentingan umum.

Pengadaan tanah bagi pembangunan untuk kepentingan umum menurut Peraturan Presiden Nomor 36 Tahun 2005 dilakukan dengan dua cara, yaitu: (1) Pelepasan atau penyerahan hak atas tanah; (2) Pencabutan hak atas tanah. Sedangkan pengadaan tanah selain bagi pelaksanaan pembangunan untuk kepentingan umum dilakukan dengan jual beli, tukar menukar, atau cara lain yang disepakati oleh para pihak. Dengan demikian pihak swasta tidak dapat melakukan pengadaan tanah dengan cara pelepasan hak, dan tidak pula dapat melakukan pencabutan hak, melainkan dengan cara jual beli, tukar menukar atau cara lain yang disepakati oleh para pihak.

Konsep kepentingan umum dalam Peraturan Presiden Nomor 36 Tahun 2005 didefinisikan dengan "kepentingan sebagian lapisan masyarakat". Di samping itu, dalam peraturan Presiden tersebut tidak ada pembatasan mengenai kriteria kepentingan umum yakni dimiliki dan dikuasi oleh pemerintah dan tidak ditujukan untuk mencari keuntungan. Hal ini berbeda dengan definisi kepentingan umum, dan pembatasanpembatasannya menurut Keppres Nomor 55 Tahun 1993. Dengan demikian konsep kepentingan umum dalam Peraturan Presiden Nomor 36 Tahun 2005 merupakan konsep yang bias, kabur dan menimbulkan multi interpretasi. Hal ini dapat menimbulkan permasalahan dalam pelaksanaannya, karena apa yang dianggap sebagai kepentingan umum oleh satu pihak, belum tentu pihak lain menganggap sama. 
Perumusan kepentingan umum dalam Keputusan Presiden Nomor 55 Tahun 1993 lebih tegas jika dibandingkan dengan rumusan kepentingan umum dalam Peraturan Presiden Nomor 36 Tahun 2005. Pengemasan pengertian umum yang demikian membuka peluang terjadinya perluasan bidang-bidang tertentu yang sebenarnya bukan masuk katagori kepentingan umum, kemudian oleh pemerintah direkayasa dan dikualifikasi sebagai kepentingan umum. Ketentuan tersebut membuka peluang kepada pihak swasta untuk meminjam tangan pemerintah guna melakukan pengadaan tanah, untuk selanjutnya diberikan kepada pihak swasta, misalnya jalan tol, tempat-tempat perbelanjaan (mall), tempat-tempat hiburan yang orientasinya untuk mencari keuntungan semata (profit oriented). ${ }^{17}$

Perluasan pengertian kepentingan umum tersebut agaknya didasarkan pada sulitnya mengukur secara kuantitatif makna "kepentingan seluruh lapisan masyarakat", sehingga pembentuk Peraturan Presiden Nomor 36 Tahun 2005 memilih memberikan pengertian kepentingan umum sebagai "kepentingan sebagian besar masyarakat". Namun demikian, perlu disadari dan diantisipasi bahwa dalam praktik di lapangan penggunaan terminologi sebagian besar lapisan masyarakat dapat menjadi kabur dan multi interpretasi. ${ }^{18}$ Oleh karena itu untuk mencegah terjadinya multi interpretasi, maka pengertian kepentingan umum tetap harus didasarkan dan tidak dipisahkan dari konsep hak menguasai negara dan fungsi sosial atas tanah, yaitu dimaksudkan semata-mata untuk sebesarbesarnya kemakmuran rakyat dan tidak diperbolehkan untuk mencari keuntungan.

Musyawarah untuk menentukan besarnya ganti rugi dalam pengadaan tanah dilakukan oleh panitia pengadaan tanah, instansi pemerintah yang memerlukan tanah dan pemegang hak atas tanah. Musyawarah untuk menentukan ganti rugi dibatasi

17 Muhadar, Korban Pembebasan Tanah...., 145.

18 Ibid., 146. 
dengan jangka waktu 90 hari kalender sejak undangan pertama (pasal 10). Dalam hal pemegang hak atas tanah tidak menerima ganti rugi yang ditetapkan oleh panitia pengadaan tanah, ia diberikan hak untuk mengajukan kepada Bupati/Walikota atau Gubernur atau Menteri Dalam Negeri. Selanjutnya Bupati/Walikota atau Gubernur mengupayakan penyelesaian mengenai bentuk dan besarnya ganti rugi tersebut dengan mempertimbangkan pendapat dan keinginan dari pemegang hak atas tanah. Setelah mendengar pendapat dan pertimbangan dari pemegang hak atas tanah, Bupati/Walikota, Gubernur atau Menteri Dalam Negeri mengeluarkan keputusan mengenai bentuk dan besarnya ganti rugi. Apabila upaya penyelesaian yang dilakukan oleh Bupati/Walikota, Gubernur atau Menteri Dalam Negeri tidak diterima oleh pemegang hak atas tanah, maka Bupati/Walikota, Gubernur atau Menteri Dalam Negeri mengusulkan pencabutan hak atas tanah kepada Presiden sesuai dengan ketentuan Undang-Undang Nomor 20 Tahun 1961 tentang Pencabutan Hak Atas Tanah dan Benda-benda yang Ada di atasnya.

Peraturan Presiden Nomor 36 Tahun 2005 ini dianggap oleh para ahli sebagai produk hukum yang sangat represif. Hal itu disebabkan karena munculnya Perpres tersebut dilatar belakangi oleh idiologi pembangunan yang berjiwa kapitalis yang lebih mementingkan pemilik modal, baik dalam negeri maupun luar negeri, sebagai upaya mendukung tercapainya pertumbuhan ekonomi. ${ }^{19}$ Jika dilihat dari subtansi Perpres tersebut yang lebih didominasi kepentingan pengusaha dan pemilik modal, hal itu bisa dilihat misalnya mengenai makna kepentingan umum yang hanya didefinisikan sebagai kepentingan sebagian besar masyarakat tanpa adanya pembatasan. Beberapa ketentuan dalam Peraturan Presiden Nomor 36 Tahun 2005 yang bersifat represif yaitu; Pertama,

${ }^{19}$ Musthofa \& Suratman, Penggunaan Hak Atas Tanah untuk Industri, (Jakarta: Sinar Grafika, 20 I3), 201. 
mengenai pengaturan ganti rugi, mestinya tidak hanya dinilai dari segi materiil. Perpres ini hanya menilai ganti rugi atas nilai tanah, tidak disebutkan ganti rugi tanaman yang tumbuh di atasnya atau nilai bangunan di atas tanah, tidak ada ketentuan bahwa ganti rugi itu menjamin kehidupan rakyat yang kehilangan tanah menjadi lebih baik. Kedua, proses pengadaan tanah, jangka waktu 90 hari untuk negosiasi yang diatur dalam Perpres ini tidak memungkinkan pemegang hak atas tanah untuk menentukan pilihan-pilihan lain, kecuali dipaksa menerima ganti rugi yang ditetapkan. Ketiga, panitia pengadaan tanah, dalam Perpres ini hanya mewakili pemerintah. Panitia pengadaan tanah ini dipastikan tak akan netral dan obyektif dalam melakukan negosiasi dalam pengadaan tanah. Tidak ada jaminan oknum dalam panitia pengadaan tanah ini tidak bermain mata dengan investor yang menyediakan modal untuk pembebasan lahan. ${ }^{20}$

Atas dasar hal di atas, maka Peraturan Presiden Nomor 36 Tahun 2005 direvisi dengan Peraturan Presiden Nomor 65 Tahun 2006 tentang Perubahan Peraturan Presiden Nomor 36 Tahun 2005 tentang Pengadaan Tanah bagi Pembangunan untuk Kepetingan Umum. Beberapa pasal yang diubah oleh Peraturan Presiden Nomor 65 Tahun 2006 yaitu; Pasal 1 ayat 3; Pasal 2 ayat 1; Pasal 3 ayat 2; Pasal 5; Pasal 6; Pasal 7;Pasal 10; Pasal 13; Pasal 15; dan Pasal 18.

4. Undang-Undang Nomor 2 Tahun 2012 tentang Pengadaan Tanah Bagi Pembangunan untuk Kepentingan Umum

Peraturan Presiden nomor 65 tahun 2006 tentang Perubahan Peraturan Presiden nomor 36 tahun 2005 tentang pengadaan tanah bagi pembangunan untuk kepentingan umum, jika dilihat dari bentuk hukumnya, tidak sesuai dengan ndangundang nomor 12 tahun 2011 tentang Pembentukan Peraturan Perundang-undangan (LN.2011-82,TLN.5234). Materi yang 
dimuat dalam Peraturan Presiden tersebut seharusnya dimuat dalam bentuk undang-undang, bukan dalam bentuk Peraturan Presiden. Di samping itu, Peraturan perundang-undangan sebelumnya dianggap belum memenuhi rasa keadilan bagi pihak yang kehilangan hak atas tanahnya. Atas dasar hal tersebut, kemudian Pemerintah mengesahkan undang-undang nomor 2 tahun 2012 tentang Pengadaan Tanah bagi pembangunan untuk kepentingan umum (LN.201222,TLN.5280).

Penjelasan umum undang-undang nomor 2 tahun 2012 menyebutkan:

“...Dalam rangka mewujudkan mayarakat yang adil, makmur, dan sejahtera berdasarkan Pancasila dan undang-undang Dasar Negara Republik Indonesia Tahun 1945, Pemerintah perlu menyelenggarakan pembangunan. Salah satu upaya pembangunan dalam kerangka pembangunan nasional yang diselenggarakan oleh Pemerintah adalah pembangunan untuk kepentingan umum. Pembangunan untuk kepentingan umum tersebut memerlukan tanah yang pengadaannya dilaksanakan dengan mengedepankan prinsip yang terkandung di dalam undang-undang Dasar Negara Republik Indonesia Tahun 1945 dan hukum tanah nasional, antara lain prinsip kemanusiaan, keadilan, kemanfaatan, kepastian, keterbukaan, kesepakatan, keikutsertaan, kesejahteraan, keberlanjutan, dan keselarasan sesuai dengan nilai-nilai berbangsa dan bernegara..."

Pengesahan undang-undang ini menunjukkan perhatian pemerintah dalam mendorong perkembangan infrastruktur. undang-undang ini bertujuan untuk menghapus hambatan terbesar dalam pembangunan infrastruktur di Indonesia, hambatan terbesar dalam pembangunan infrastruktur adalah dalam proses pengadaan tanahnya. Menurut Antara News, sebagaimana dikutip Roosdiono, pada tahun 2011 pemerintah Indonesia menawarkan 79 proyek infrastruktur kepada investor 
di bawah skema Public Privat Partnership (kerja sama pemerintah dengan swasta). ${ }^{21}$

Pengadaan tanah dalam undang-undang ini didefiniskan dengan "kegiatan menyediakan tanah dengan cara memberi ganti kerugian yang layak dan adil kepada pihak yang berhak". Kepentingan umum didefinisikan dengan "kepentingan bangsa, negara, dan masyarakat yang harus diwujudkan oleh pemerintah dan digunakan sebesar-besarnya untuk kemakmuran rakyat". Makna kepentingan umum dalam undang-undang ini merupakan norma yang kabur (vage normen), agar tidak menimbulkan interpretasi yang beragam, maka harus dituliskan secara jelas kegiatan yang dimaksud meliputi aktifitas apa, dan bagaimana harus dilaksanakan. Nampaknya undang-undang nomor 2 tahun 2012 tentang pengadaan tanah bagi pembangunan untuk kepentingan umum, dapat dikatakan identik dengan Peraturan Menteri Dalam Negeri nomor 15 tahun 1975 dan Peraturan Menteri Dalam Negeri nomor 2 tahun 1976 yang mengedepankan pada pengkaburan makna kepentingan umum. ${ }^{22}$ Dalam undangundang ini, tidak ada kriteria dan batasan mengenai kepentingan umum, yakni dimiliki, dikuasai oleh pemerintah, dan tidak untuk mencari keuntungan, sehingga dapat menimbulkan penafsiran yang beragam mengenai makna dan bidang-bidang kepentingan umum. Bahkan dalam pasal 11 ayat (2) dijelaskan;

“Dalam hal instansi yang memerlukan pengadaan tanah untuk kepentingan umum sebagaimana dimaksud dalam pasal 10 ayat (1) adalah Badan Usaha Milik Negara, tanahnya menjadi milik Badan Usaha Milik Negara"

Kemudian pasal 12 ayat (1) menjelaskan;

"Pembangunan untuk kepentingan umum sebagaimana dimaksud dalam pasal 10 huruf $b$ sampai dengan huruf $r$ wajib

${ }^{21}$ Roosdiono, "Undang-undang Nomor 2 tahun 2012", Makalah, t.t., I.

22 Imam Koeswahyono, "Melacak Dasar Konstitusional Pengadaan Tanah untuk Kepentingan Pembangunan Bagi Umum", Makalah, tt, 5. 
diselenggarakan pemerintah dan dapat bekerja sama dengan Badan Usaha Milik Negara, Badan Usaha Milik Daerah, atau Badan Usaha Swasta".

Rumusan pasal 10 ayat (1) dan pasal 12 ayat (1) di atas sebenarnya mengingkari tentang konsep kepentingan umum, yakni pembangunan yang selanjutnya dikuasai, dimiliki pemerintah, serta tidak untuk mencari keuntungan (non profit oriented), nampaknya undang-undang ini terkooptasi oleh kepentingan pemilik modal besar yang nyata berkarakter profit oriented dengan mengatasnamakan kepentingan umum, mekanisme pengadaan tanah untuk kepentingan swasta seharusnya melalui jual beli, bukan mendompleng pemerintah untuk melakukan pengadaan tanah. ${ }^{23}$ Jika dikaji secara mendalam kepentingan pemilik modal swasta sangat nampak sekali dalam undang-undang ini, hal itu dapat dilihat dalam pasal 13 huruf a yang memasukkan "jalan tol, dan saluran telekomunikasi" dalam katagori kepentingan umum, padahal jalan tol dan saluran telekomunikasi yang dimiliki oleh investor swasta bukan masuk katagori kepentingan umum, karena jelas tujuannya profit oriented. ${ }^{24}$

Pengadaan tanah bagi pembangunan untuk kepentingan umum dilakukan dengan cara musyawarah untuk menentukan besarnya ganti kerugian, musyawarah dilakukan oleh pemegang hak atas tanah dengan Lembaga Pertanahan, musyawarah dilakukan dalam jangka waktu 30 (tiga puluh) hari kerja. Hasil kesepakatan dalam musyawarah menjadi dasar pemberian ganti kerugian kepada pihak yang berhak yang dimuat dalam berita acara (pasal 37). Apabila tidak terjadi kesepakatan mengenai bentuk dan besarnya ganti kerugian, pihak yang berhak dapat mengajukan keberatan kepada Pengadilan Negeri setempat dalam waktu paling lama 14 (empat

${ }^{23}$ Imam Koeswahyono, "Suatu Catatan Kritis Atas Undang-Undang Pengadaan Tanah Untuk Pembangunan Nomor 2 Tahun 20 I2", Makalah, tt, 9.

${ }^{24}$ Ibid., 10. 
belas) hari kerja setelah musyawarah penetapan ganti kerugian selesai dilaksanakan (pasal 38 ayat 2). Berdasarkan pengajuan keberatan dari pihak yang berhak tersebut, Pengadilan Negeri memutus bentuk dan/atau besarnya ganti kerugian dalam waktu paling lama 30 (tiga puluh) hari kerja sejak diterimanya pengajuan permohonan keberatan (pasal 38 ayat 3). Apabila pihak yang berhak masih keberatan dengan putusan Pengadilan Negeri tersebut, dalam jangka waktu 14 (empat belas) hari ia diberikan hak untuk mengajukan kasasi ke Mahkamah Agung, selanjutnya Mahkamah Agung wajib memberikan putusan dalam jangka waktu paling lama 30 (tiga puluh) hari kerja sejak permohonan kasasi diterima oleh Mahkamah Agung. Putusan Mahkamah Agung yang telah mempunyai kekuatan hukum tetap menjadi dasar pembayaran ganti kerugian kepada pihak yang mengajukan keberatan (pasal 38 ayat 4).

Apabila para pihak menolak bentuk dan besarnya ganti kerugian, tetapi tidak mengajukan keberatan ke Pengadilan Negeri, atau mengajukan tetapi tidak sesuai dengan waktu yang telah ditentukan, karena hukum pihak yang berhak dianggap telah menerima bentuk dan besarnya ganti kerugian (pasal 39). Dalam undang-undang ini juga diterapkan lembaga konsinyasi (menitipkan ganti kerugian di Pengadilan Negeri), yaitu:

a. Dalam hal pihak yang berhak menolak bentuk dan besarnya ganti kerugian berdasarkan musyawarah atau putusan pengadilan;

b. Pihak yang berhak tidak diketahui keberadaannya;

c. Objek pengadaan tanah menjadi objek perkara di pengadilan, masih dipersengketakan kepemilikannya, diletakkan sita oleh pejabat yang berwenang, dan menjadi jaminan di bank (pasal 42).

Penerapan konsep konsinyasi yang diatur dalam undangundang ini sebenarnya mengadopsi konsep konsinyasi yang terdapat dalam pasal 1404 KUHPerdata. Namun menurut Maria SW. Sumardjono, menganalogkan konsep konsinyasi dalam 
pasal 42 ayat (1) Undang-Undang Nomor 2 Tahun 2012 dengan konsep konsinyasi yang diatur dalam pasal 1404 KUHPerdata adalah kurang tepat, dalam hal ini Maria SW. Sumardjono menyatakan:

"Secara konsep penggunaan lembaga penitipan ganti kerugian pada Pengadilan Negeri adalah keliru, pasal 1404 KUHPerdata mengatur tentang lembaga penawaran pembayaran diikuti dengan penitipan pada Pengadilan Negeri dilandasi pada hubungan yang bersifat keperdataan antara para pihak yang berawal dari adanya hubungan utang piutang. Pengadaan tanah adalah perbuatan hukum pemerintah untuk memperoleh tanah dari pemegang hak atas tanah dengan memberikan ganti kerugian. Jelaslah bahwa hubungan antara pemerintah dengan pemegang hak atas tanah bukan hubungan utang piutang yang bersifat keperdataan. Ketika pemegang hak atas tanah menolak ganti kerugian yang ditawarkan oleh instansi pemerintah yang memerlukan tanah, maka tindakan untuk menitipkan uang ganti kerugian di Pengadilan Negeri merupakan tindakan sepihak, bahwa dengan telah dititipkannya uang ganti kerugian itu seolaholah sudah terjadi kesepakatan untuk menerima ganti kerugian tersebut dan tanggung jawab untuk membayar ganti rugi dipandang telah dilaksanakan, dan dengan demikian hal tersebut memberikan legitimasi bagi instansi yang memerlukan tanah untuk dapat memulai kegiatan fisik pembangunannya." 25

Jika dikaji secara mendalam, Undang-Undang Nomor 2 Tahun 2012 memiliki beberapa kelemahan. Menurut Maria SW. Sumardjono, beberapa kelemahan Undang-Undang Nomor 2 Tahun 2012 antara lain:

a. Undang-Undang Nomor 2 Tahun 2012 menabrak hukum sebagai sistem. Jika dalam peraturan perundang-undangan

\footnotetext{
25 Maria Soemardjono, "Anatomi UU Nomor 2 Tahun 2012 tentang Pengadaan Tanah bagi Pembangunan untuk Kepentingan Umum Tinjauan Filosofis, Yuridis, dan Sosiologis", Makalah disampaikan pada Sosialisasi Undang-Undang Nomor 2 Tahun 2012, diselenggarakan oleh Direktorat Utama Bidang Pembinaan dan Pengembangan Hukum Pemeriksaan Keuangan RI, Jakarta, 22 Maret 2012, 18.
} 
sebelum Undang-Undang Nomor 2 Tahun 2012 (keppres Nomor 55 Tahun 1993, Perpres Nomor 36 Tahun 2005 jo Perpres Nomor 65 Tahun 2006), membedakan antara konsep pengadaan tanah dan konsep pencabutan hak atas tanah, namun Undang-Undang Nomor 2 Tahun 2012 meninggalkan konsepsi ini dengan tidak menyinggung sama sekali acara pencabutan hak atas tanah ketika musyawarah untuk mencapai kesepakatan lokasi pembangunan maupun pemberian ganti kerugian menemui kegagalan, sedangkan lokasi tidak dapat dipindahkan. Semua keberatan/penolakan pemegang hak atas tanah diselesaikan melalui lembaga peradilan dengan sama sekali menafikan acara pencabutan hak atas tanah.

b. Undang-Undang Nomor 2 Tahun 2012 menabrak UndangUndang Nomor 26 Tahun 2007 tentang Penataan Ruang. Pasal 7 ayat (2) menyebutkan; "dalam hal pengadaan tanah dilakukan untuk infrastruktur minyak, gas dan panas bumi pengadaannya diselenggarakan berdasarkan rencana strategis dan rencana kerja instansi yang memerlukan tanah sebagimana dimaksud dalam ayat (1) huruf a dan d. Ada dua hal yang dapat dicatat sehubungan dengan rumusan pasal 7 dan dampaknya; pertama, pasal 7 ayat (2) mengecualikan pengadaan tanah untuk infrastruktur migas dan panas bumi dari keharusan untuk menaati rencana tata ruang wilayah dan rencana pembangunan nasional/daerah. Pengecualian ini justru dapat dimaknai melanggar ketentuan UndangUndang Nomor 26 Tahun 2007, karena adanya kewajiban untuk menaati rencana tata ruang, bahkan pelanggaran terhadap kewajiban ini dapat berujung pada sanksi pidana. Kedua, jika karena karakteristik kegiatan migas dan panas bumi dinilai mempunyai kekhususan, maka jalan keluarnya bukan dengan merusak sistem penataan ruang dengan merumuskan pengecualian dalam pasal 7 ayat (2), tetapi dapat diusahakan dengan menggunakan instrumen 
peninjauan kembali rencana tata ruang yang dimungkinkan melalui pasal 16 Undang-Undang Nomor 26 Tahun 2007, dan yang telah diatur lebih lanjut dalam Peraturan Pemerintah Nomor 15 Tahun 2010 tentang Penyelenggaraan Penataan Ruang. ${ }^{26}$

Berdasarkan uraian di atas, ada dua hal yang perlu diperhatikan terkait dengan keberadaan Undang-Undang Nomor 2 Tahun 2012; pertama, undang-undang itu perlu direvisi kembali, artinya kembali kepada sistem perolehan hak atas tanah yang ada, yaitu jika tercapai kata sepakat, maka mekanismenya melalui pengadaan tanah, namun jika tidak tercapai kata sepakat maka melalui pencabutan hak atas tanah, jika tidak demikian, maka pasal 18 UUPA, dan Undang-Undang Nomor 20 Tahun 1961 tentang pencabutan hak atas tanah dan benda-benda di atasnya harus dicabut; kedua, lembaga penitipan (konsinyasi) diperuntukkan dalam hal-hal tertentu saja, yakni jika pemegang hak atas tanah tidak diketahui keberadaannya, obyek pengadaan tanah sedang menjadi sengketa di pengadilan, diletakkan sita jaminan, dan sedang dijaminkan dengan hak tanggungan. ${ }^{27}$

\section{Formulasi Keterlibatan Swasta dalam Pengadaan Tanah untuk Kepentingan Umum}

Landasan hukum yang dijadikan dasar mengenai kerjasama pemerintah dengan badan usaha swasta dalam pelaksanaan pembangunan untuk kepentingan umum adalah pasal 12 ayat 1 Undang-Undang Nomor 2 Tahun 2012 tentang Pengadaan Tanah bagi Pembangunan untuk Kepentingan Umum.

Pasal 12 menyebutkan:

1. Pembangunan untuk kepentingan umum sebagaimana dimaksud dalam pasal 10 huruf $\mathrm{b}$ wajib diselenggarakan

\footnotetext{
26 Ibid., 25.

27 Maria Soemardjono, Anatomi..., 4I; lihat pula Sudjito et all, Restorasi Kebijakan Pengadaan, Perolehan, Pelepasan dan Pendayagunaan Tanah Serta Kepastian Hukum di Bidang Investasi, (Yogyarakta: Tugujogja Pustaka, 20 I2), 3.
} 
pemerintah dan dapat bekerja sama dengan Badan Usaha Milik Negara, Badan Usaha Milik Daerah, atau Badan Usaha Swasta.

2. Dalam hal pembangunan pertahanan dan keamanan nasional sebagaimana dimaksud dalam pasal 10 huruf a, pembangunannya diselenggarakan sesuai dengan ketentuan peraturan perundang-undangan.

Pasal 12 ayat (1) sebagaimana uraian penulis sebelumnya merupakan norma yang kabur (vage normen) sepanjang mengenai klausul "...dapat bekerja sama dengan badan usaha milik negara, badan usaha milik daerah, atau badan usaha swasta". Bentuk dan model kerjasama yang bagaimana dalam pembangunan untuk kepentingan umum yang dapat membawa kesejahteraan masyarakat, tidak dijelaskan dalam pasal 12 Undang-Undang Nomor 2 Tahun 2012, Bahkan dalam penjelasannya dinyatakan "cukup jelas".

Jika dikaji dari latar belakang historisnya, munculnya pasal 12 di atas dilatarbelakangi oleh keinginan pemerintah untuk mempercepat pembangunan infrastruktur di Indonesia, sementara dana yang dimiliki pemerintah tidak cukup untuk membangun infrastruktur. Untuk mengatasi permasalahan tersebut, pihak swasta perlu dilibatkan dalam pelaksanaan pembangunan untuk kepentingan umum. Mekanisme keterlibatan pihak swasta dalam pelaksanaan pembangunan untuk kepentingan umum, lazimnya dikenal dengan Kerjasama Pemerintah Swasta (KPS), atau Public Privat Partnership (PPP). Pada dasarnya peran pemerintah dalam menyelenggarakan pembangunan adalah untuk mensejahterakan masyarakat, pembangunan yang berhubungan dengan kepentingan umum pada mulanya hanya menjadi peran dan kewajiban pemerintah, namun best practices yang terjadi di beberapa negara yang sudah berhasil pembangunan infrastrukturnya, pemerintah mengajak peran swasta yang dikenal dengan Public Privat Partnership. Public Privat Partnership (PPP) merupakan bentuk kerjasama pemerintah dengan swasta atau sebaliknya swasta mengajak kerjasama dengan pemerintah untuk melaksanakan 
pembangunan. Apa yang diperjanjikan antara pemerintah dengan swasta secara subtansial menganut asas kebebasan berkontrak. ${ }^{28}$

Ratio legis dari munculnya pasal 12 ayat (1) Undang-Undang Nomor 2 Tahun 2012 adalah sebagai berikut:

"Hukum positif pasca Indonesia merdeka, tidak ada undangundang yang mengatur pengadaan tanah oleh swasta untuk kepentingannya. Dirasakan sekarang ada penguasaan dan pemilikan oleh swasta yang luasnya tidak lagi proporsional atau relevan untuk bidang usahanya. Selain itu realitas penguasaan tanah-tanah oleh swasta saat ini ada sebagian yang diterlantarkan, yang indikasinya sekitar 6,1 juta hektar. Luasan itu sama saja dengan puluhan kali luasnya dari luas tanah negara tetangga. Hal ini sangat merugikan rakyat, bangsa, dan negara, selain dari pada itu, ketika pengadaan tanah tidak ada peran negara, tidak ada pengawasan dari negara, dan tidak pula ada pengendalian dari negara maka terjadi privatisasi besar-besaran oleh swasta yang pada ujungnya negara tidak lagi mempunyai koridor hukum untuk melakukan peranannya secara baik. Sementara pemerintah tidak mempunyai data yang valid dan terpercaya mengenai berapa luas tanah yang dikuasai/dimiliki swasta yang diperoleh melalui pengadaan tanah. Hal ini terjadi karena kekosongan hukum mengenai tidak ada kewajiban bagi swasta untuk melaporkan tanah-tanahnya. Beranjak dari ratio legis yang disebut di atas, pemerintah perlu menjalankan peran pengendalian, peran pengawasan, dan peran pengaturan atas pengadaan-pengadaan tanah yang dilaksanakan oleh swasta untuk kepentingannya dengan undang-undang." ${ }^{29}$

Pengadaan tanah bagi kepentingan swasta pada awalnya disebutkan secara explisit dalam pasal 4, 11, dan 12 Rancangan Undang-Undang tentang Pengadaan Tanah untuk Pembangunan. Pasal 4 RUU tentang pengadaan tanah untuk pembangunan menentukan: "Pengadaan tanah untuk pembangunan meliputi; (a) Pengadaan tanah untuk kepentingan umum; dan (b) Pengadaan tanah untuk kepentingan usaha swasta". Selanjutnya Pasal 11 RUU

28 Anonim, Naskah Akademik Rancangan Undang-undang tentang Pengadaan Tanah untuk Pembangunan, (Jakarta: Mimeo, 2010), 51 .

29 Ibid. 
menentukan:"Pengadaan tanah untuk kepentingan usaha swasta dilakukan dengan perencanaan sesuai dengan rencana tata ruang wilayah atau rencana pembangunan nasional dan daerah". Selanjutnya Pasal 12 RUU menentukan; "Pengadaan tanah untuk kepentingan usaha swasta dilakukan secara langsung dan sukarela oleh pihak swasta yang memerlukan tanah dengan pihak yang berhak".

Dalam perkembangannya setelah disahkan menjadi undangundang rumusan pasal 4, 11, dan 12 tidak muncul, sehingga yang disepakati oleh Dewan Perwakilan Rakyat dan pemerintah adalah rumusan sebagaimana yang tertuang dalam pasal 12 ayat (1) Undang-Undang Nomor 2 Tahun 2012 yang berbunyi: "Pembangunan untuk kepentingan umum sebagaimana dimaksud dalam pasal 10 huruf $b$ wajib diselenggarakan pemerintah dan dapat bekerja sama dengan Badan Usaha Milik Negara, Badan Usaha Milik Daerah, atau Badan Usaha Swasta".

Pengadaan tanah untuk kepentingan umum yang dikembangkan di negara-negara Uni Eropa, tidak hanya dijalankan oleh pemerintah semata, tetapi juga bekerjasama dengan pihak badan usaha swasta dalam skema Public Privat Partnership atau Kerjasama Pemerintah Swasta (KPS). Meskipun Kerjasama Pemerintah Swasta (KPS) bukanlah satu-satunya cara (miracle way) kesuksesan pelaksanaan pengadaan tanah untuk pembangunan, namun lebih berpeluang jika semua peran dijalankan oleh pemerintah. Lesson learned yang dipraktikkan di dunia internasional itulah yang dicoba dikembangkan di Indonesia. Dengan demikian pelaksanaan pengadaan tanah untuk pembangunan ada 3 (tiga) pola, yaitu: (1) pengadaan tanah oleh pemerintah; (2) pengadaan tanah oleh pemerintah bekerjasama dengan swasta; (3) pengadaan tanah oleh swasta untuk kepentingan umum atau untuk kepentingan privat. $^{30}$

${ }^{30}$ lbid., 6l. 
Kerjasama Pemerintah Swasta (KPS) atau Public Privat Partnership (PPP) didefinisikan oleh Wiiliam J. Paren dari USAID Environmental Services Program sebagai: "an agreement or contract, between a public entity and private party, under which: (a) private party understakes government function for specified period of time; $(b)$ the private party receives compensation for performing the function, directly or indirectly, (c) the private party is liable for the risks arising form performing the function and, (d) the public facilities, land or other resources may be transferred or made available to the private party". ${ }^{31}$

Definisi yang lain dari Kerjasama Pemerintah Swasta atau Public Privat Partnership (PPP) adalah "partnership between the public sector and the private sector for the the purposes of desaining, planning, financing, contructing and/or operating project wich would be regarded traditionally as falling within the remit of the public sector". ${ }^{32}$

Kerjasama Pemerintah Swasta (KPS) dapat juga dimaknai sebagai kerjasama antara pemerintah dengan sektor Swasta berdasarkan kapasitas masing-masing pihak untuk memenuhi tujuan bersama yang disepakati dalam bidang kebutuhan umum dengan mempertimbangkan kesesuaian alokasi sumber daya resiko, dan imbal jasa/penghargaan (reward). ${ }^{33}$ Dalam arti yang lain Kerjasama Pemerintah Swasta adalah kesepakatan antara dua belah pihak atau lebih yang memungkinkan mereka saling bekerjasama untuk mencapai tujuan bersama, yang mana masing-masing pihak berperan berdasarkan tingkat tanggungjawab dan kekuasaannya, tingkat investasi atas sumber daya, level potensi resiko dan keuntungan bersama. ${ }^{34}$

Kerjasama Pemerintah Swasta (KPS) dapat pula dipandang sebagai kemitraan antara pemerintah dan sektor swasta dalam

3! Sie Infokum, tt. Kerjasama Pemerintah dengan Badan Usaha Swasta dalam penyediaan Infrastruktur, (Jakarta: Ditama Binbangkum), I .

32 Maniam Kaliannam et all, "Public Privat Partnership for E-Government Servis: Lesson from Malaysia", International Juornal of Institutions and Economies, Vol. 2. No. 2. Oktober, 20 I0, 208.

33 Bachtiar Rifaii, "Meninjau Kembali Kebijakan Kerjasama Pemerintah dan Swasta dalam Pembangunan Infrastruktur di Indonesia; Sebuah Perspektif Pekerjaan Rumah Bagi Indonesia", Ringkasan Laporan Penelitian, (Jakarta: LIPI, 20I I), 5.

${ }^{34}$ Ibid., 6. 
penyediaan infrastruktur, yang mana sebelumnya dilakukan sepenuhnya oleh pemerintah, masing-masing pihak yang terlibat dalam kemitraan memperoleh manfaat secara relatif terhadap yang lain menurut kinerja dalam sektor-sektor tertentu. Kombinasi tingkat kemanfaatan antar mitra maupun antar sektor kegiatan secara langsung mempengaruhi kesuksesan pelaksanaan Kerjasama Pemerintah Swasta. ${ }^{35}$ Dalam skema Kerjasama Pemerintah Swasta (KPS), terdapat tiga pihak yang mempunyai peran masing-masing, yaitu pemerintah atau pemerintah daerah selaku regulator (pembuat kebijakan); perbankan selaku penyandang dana; dan pihak swasta/BUMN/BUMD selaku special purpose company yang bertanggung jawab atas pelaksanaan suatu proyek mulai dari desain, kontruksi, pemeliharaan dan operasional. ${ }^{36}$

Kerjasama Pemerintah Swasta (KPS) merupakan alat untuk meningkatkan efisiensi dan meningkatkan kualitas produk-produk dan pelayanan publik. Tujuan bersama yang hendak dicapai dengan menggunakan skema KPS antara lain untuk meningkatkan efektifitas dan efesiensi dalam pelaksanaannya, meningkatkan kualitas produk-produk dan pelayanan publik, dan adanya pembagian modal, resiko, dan kompetensi atau keahlian sumber daya manusia secara bersama-sama. Pada sisi yang lain, KPS tidak hanya dipandang dari aspek publik dan privat saja, akan tetapi merupakan triangle synergi antara pemerintah (government), swasta (business), dan masyarakat (communities). ${ }^{37}$

Public Privat Partanership (PPP) atau Kerjasama Pemerintah Swasta (KPS) sudah dilaksanakan di beberapa negara seperti Amerika, Inggris, Korea Selatan, India, Thailand, Filipina, dan

\footnotetext{
35 Ibid., 5.

${ }^{36}$ Dwinanta Utama, "Prinsip dan Strategi Penerapan Public Private Partnership dalam Penyediaan Infrastruktur Transportasi”, Jurnal Sain dan Teknologi Indonesia, Vol. 12. No. 3 Desember, 20I0, 146.

${ }^{37}$ Bambang Susanto dan Muhammad Ali Berawi, 2012."Perkembangan Kebijakan Pembiayaan Infrastruktur Transportasi Berbasis Kerjasama Pemerintah Swasta di Indonesia", Jurnal Transportasi, Vol. 12. No. 2 Agustus, 2012, 94.
} 
Afrika Selatan. Lazimnya di beberapa negara, kegiatan pembangunan infrastruktur seperti kereta api, jalan, energi, ketenaga listrikan, dan air bersih sepenuhnya dimiliki, dilakukan dan dibiayai oleh pemerintah. Namun dalam perkembangannya, tidak setiap negara memiliki kapasitas yang memadai dalam penyediaan infrastruktur, khususnya dalam aspek pembiayaan. Pada sisi lain, beberapa kegiatan infrastruktur yang dikelola oleh Badan Usaha Milik Negara (BUMN), national firms tidak menunjukkan kinerja yang optimal. Untuk mengakomodasi keterbatasan pembiayaan kegiatan pembangunan infrastruktur sekaligus mendorong optimalisasi kinerja, Public Privat Partnership (PPP) dikembangkan di beberapa negara sejak awal tahun 1990an. ${ }^{38}$

Beberapa faktor yang menyebabkan pemerintah perlu melibatkan pihak swasta dalam pelaksanaan pembangunan untuk kepentingan umum, yaitu (1) kurangnya dana pemerintah; (2) infrastruktur yang ada sudah tidak memadai baik dari segi kuantitas maupun kualitasnya; (3) keahlian yang dimiliki oleh sektor swasta. ${ }^{39}$ Pendapat serupa disampaikan Dwinanta Utama, penerapan Kerjasama Pemerintah Swasta (KPS) akan semakin penting di masa mendatang disebabkan; keterbatasan sumber daya pemerintah, meningkatnya permintaan, efisiensi dalam pelayanan, kualitas dan kuantitas pelayanan rendah, penguasaan teknologi, menghilangkan monopoli dan birokrasi. ${ }^{40}$

Proyek Kerjasama Pemerintah Swasta (KPS) digagas untuk mengundang lebih banyak peran dan inisiatif swasta dalam percepatan pembangunan infrastruktur di Indonesia. Sementara dana yang disediakan oleh pemerintah dipastikan tidak mampu menutupi keseluruhan biaya yang dibutuhkan. Dengan menggandeng pihak swasta, kebutuhan dana diharapkan dapat

\footnotetext{
38 lbid., I.

39 Irwan Prasetyo, "Kerjasama Pemerintah Swasta dalam Pembangunan Perkotaan", Buletin Tata Ruang, Edisi November-Desember 2009, I.

${ }^{40}$ Dwinanta Utama, "Prinsip dan Strategi Penerapan..., 149.
} 
tercukupi. Pemerintah memberikan jaminan bahwa proyek KPS prioritas yang dibangun oleh pihak swasta dan dijamin cukup untuk mengembalikan nilai investasinya yang disebut sebagai resiko pengembalian atas investasi. Pemerintah juga akan memberikan jaminan terhadap resiko politik, apabila selama masa konsesi pemerintah melakukan perubahan peraturan yang mengakibatkan proyek dipandang tidak akan mampu mengembalikan investasi sesuai dengan yang diperjanjikan, pemerintah akan memberikan kompensasi kepada penyelenggara proyek. ${ }^{41}$

\section{Tinjauan Hukum Islam terhadap Pengadaan Tanah untuk Kepentingan Umum}

Tujuan disyariatkannya Islam atau yang dikenal maqâshid alsyarî'ah meliputi perlindungan terhadap agama (hifzh al-dîn), perlindungan terhadap keturunan (hifzh al-nasl), perlindungan terhadap jiwa (hifzh al-nafs), perlindungan terhadap aqal (hifzh al'aql), dan perlindungan terhadap harta benda (hifda al-mâl ).42 Hak Milik Individu dihargai dan dilindungi, sehingga seseorang tidak boleh mengganggu hak milik orang lain. Barang siapa mengganggu hak milik individu akan mendapat ancaman sanksi hukum yang berat. Al-Qur'an surat al-Maidah ayat 38 menyebutkan: "Pencuri laki-laki dan pencuri perempuan potonglah kedua tangannya sebagai balasan atas perbuatan yang dilakukannya dan sebagai siksaan dari Allah". Kemudian Nabi Muhammad saw pernah bersabda: "Barang siapa berupaya mengambil harta milik orang lain dengan jalan yang tidak benar, maka ia akan ketemu Allah (setelah meninggal) di mana Allah marah kepadanya". ${ }^{43}$

Menurut Muhammad Abu Zahrah, semua hak dalam Islam dibatasi oleh prinsip menolak munculnya kerugian dan menarik munculnya manfaat bagi masyarakat umum. Hak-hak milik dalam

\footnotetext{
${ }^{41}$ Aid for Development, Kerjasama Pemerintah Swasta (KPS) Pembiayaan KPS Infrastruktur dan Kesesuaiannya pada KPS Sosial , (Jakarta: Mimeo, 20I2), 2-3.

42 Thohir Luth, Syariat Islam Mengapa Takut, (Malang: UB Press, 201 I ), I I - 13.

${ }^{43}$ Ahmad ibn al-Hanbal, Musnad Ahmad, Hadis Nomor 3946.
} 
Islam ditujukan untuk mewujudkan mashlahah bagi masyarakat umum, selain berfungsi merealisir kemaslahatan bagi pemiliknya. Perlu dilakukan kalkulasi mashlahah antara mashlahah bagi pemilik hak tersebut dengan kerugian yang menimpa orang lain secara khusus dan masyarakat umum. Jika kerugian yang menimpa orang lain lebih besar dari mashlahah bagi pemiliknya, maka hak milik tersebut dibatasi demi menolak kerugian yang menimpa orang lain tersebut. ${ }^{4}$

Dalam kaitannya dengan pengadaan tanah bagi pembangunan untuk kepentingan umum, Islam memperbolehkan pembebasan atau pencabutan hak milik dari pemiliknya manakala ia tidak bisa menggunakan hak miliknya secara baik, sementara tidak menemukan jalan lain untuk mencegahnya. Berkenaan dengan pembebasan tanah atau pencabutan hak atas tanah, 45 menurut Muhammad Abu Zahrah ada tiga kondisi yang memperkenankan pengambilalihan hak milik individu tersebut dengan paksa, yaitu:

Pertama, pencabutan kepemilikan individu demi mewujudkan manfaat bagi orang banyak, seperti pencabutan hak milik atas tanah untuk pembuatan atau pelebaran jalan raya, perluasan masjid yang sudah tidak dapat menampung jamaah. Tanah milik individu di sekitarnya boleh dibeli dengan paksa, namun dengan harga yang layak dan wajar agar tidak menimbulkan kerugian yang besar bagi para pemilik tanah tersebut. Bolehnya pencabutan hak milik tanah individu yang ada di sekitar masjid untuk perluasan masjid dengan memberikan ganti atau pembayaran sesuai harganya walaupun harus dengan paksa dianalogikan kepada perluasan masjid alHaram yang pernah dilakukan oleh Khalifah Umar ibn al-Khattab. Pada saat itu rumah para sahabat berdempetan dengan masjid. Umar memerintahkan untuk membeli tanah-tanah yang ada di sekitar masjid itu. Sebagian mereka menerima dengan suka rela, namun sebegian mereka awalnya menolak sehingga Umar

\footnotetext{
${ }^{44}$ Muhammad Abu Zahrah, al-Takâful al-ljtimâ'l, (Kairo ; Dar al-Fikr al-Arabi, tt), 53.

${ }^{4}$ Istilah pembebasan dan pencabutan hak atas tanah dalam konsep hukum Islam dimaknai sama yaitu pengambilan tanah oleh penguasa untuk kepentingan umum.
} 
melakukannya dengan paksa dengan cara meletakkan uang pembayarannya di tempat ruang penjaga Ka'bah. ${ }^{46}$ Kedua, pencabutan hak milik individu dalam rangka membayarkan hutang ketika pemilik hak milik ini berkecukupan tapi enggan membayar hutang tersebut. Hakim berfungsi sebagai mediator dengan para piutang yang melapor kepadanya untuk membayarkan hutang pemilik hak individu tersebut; ketiga, membeli harta orang lain dengan cara syuf'ah. ${ }^{47}$

Menurut Muhammad Faruq Nabhan, ada dua kondisi yang menyebabkan bolehnya hak milik individu bisa dicabut atau dialihkan kepada orang lain atau pihak lain. pencabutan hak milik bisa dilakukan apabila kondisi darurat menuntutnya untuk menjaga kemaslahatan individu lain atau karena adanya darurat yang menuntut kemaslahatan (kepentingan) umum.

Kondisi pertama melalui sistem syuf'ah yang diakui syariat dan yang dibolehkan bagi tetangga atau orang yang berserikat dalam kepemilikan hak bersama, yakni apabila seseorang menjual miliknya kepada orang lain, sedang ia tahu bahwa penjualannya ini menimbulkan bahaya, maka bolehlah tetangga itu menuntut uang syuf'ah kepada pembeli dan tetangga itu berhak didahulukan daripada orang asing dalam safaqah (wajib menjual) kepadanya.

Kondisi kedua, hak individu dapat dicabut karena adanya kemaslahatan (kepentingan) umum yang menuntutnya. Penguasa atau pemerintah berhak mencabut hak milik individu ini karena kondisi darurat, tetapi dengan syarat tuntutan kebutuhan yang ada tidak karena ketidak sukaan penguasa atau karena munculnya bahaya kepada seorang individu saja.

Salah satu contoh kondisi yang membolehkan pencabutan hak milik individu untuk kepentingan umum adalah pencabutan hak milik tanah-tanah di sekitar masjid yang sangat dibutuhkan dalam perluasan masjid tersebut. Selain itu, juga adanya keperluan darurat

\footnotetext{
${ }^{46}$ Abu Zahrah, al-Milkiyyah wa al-Nadhariyyah al-'Aqd fi al-Syari'ah al-Islâmiyyah, (Mesir: Mathba'ah Fathullah al-Yas, tt.), 143.

47 Ibid, | 42- 44.
} 
terhadap pelebaran jalan raya yang membutuhkan pembebasan tanah di sekitarnya. Pencabutan hak milik individu dan pembebasan tanah milik individu ini tentunya disertai dengan pemberian ganti lahan atau pembayaran yang sesuai dengan harga umumnya, kalau pemilik tanah ini menolak, maka penguasa boleh melakukan pemaksaan. ${ }^{48}$

\section{Penutup}

Dinamika pengaturan pengadaan tanah untuk kepentingan umum yang melibatkan swasta dalam peraturan perundangundangan bervariasi; dalam PMDN Nomor 15 Tahun 1975 pihak swasta dapat terlibat dalam pengadaan tanah, dalam Keppres Nomor 55 Tahun 1993, Perpres Nomor 36 Tahun 2005, jo Perpres Nomor 65 Tahun 2006, swasta tidak dapat terlibat dalam pengadaan tanah, dalam Undang-Undang Nomor 2 Tahun 2012 swasta dapat terlibat dalam pengadaan tanah melalui mekanisme kerjasama pemerintah dengan swasta dalam pelaksanaan pembangunan.

Formulasi keterlibatan badan usaha swasta dalam pengadaan tanah untuk kepentingan umum, yaitu melalui model Kerjasama Pemerintah Swasta (Public Privat Partnership), dalam kerjasama ini pemerintah menyediakan tanah melalui mekanisme pengadaan tanah, sedangkan pihak swasta melaksanakan pembangunan untuk kepentingan umum, setelah jangka waktu konsesi selesai swasta mengembalikan kepada pemerintah sesuai dengan perjanjian yang disepakati.

Dalam perspektif hukum Islam, pengadaan tanah untuk kepentingan umum, baik melalui pembebasan hak maupun pencabutan hak diperbolehkan apabila peruntukannya untuk kepentingan umum atau kemaslahatan umum, bukan untuk kepentingan komersil, dan yang harus melalukan pembebasan dan pencabutan hak atas tanah pemerintah bukan pihak swasta.

${ }^{48}$ Ali al-'Afif, Mukhtashar Ahkâm al-Mu'amalât al-Syar'iyyâh, (Makkah: Mathba'ah al-Sunnah alMuhammadiyyah, tt.), 38. Lihat juga Mustofa Ahmad al-Zarqa, al-Madkhal al-Figh al-'Amm, II (Mathba'ah al-Jami'ah al-Suriyah,tt.), 227. 


\section{Daftar Pustaka}

'Afif (al-), Ali. Mukhtasar Ahkâm al-Mu'âmalat al-Syar'iyyat. Makkah: Matba'ah al-Sunnah al-Muhammadiyah, t.t.

Aid for Development. Kerjasama Pemerintah Swasta (KPS) Pembiayaan KPS Infrastruktur dan Kesesuaiannya pada KPS Sosial. Jakarta: Mimeo, 2012.

Anonim. Naskah Akademik Rancangan Undang-undang tentang Pengadaan Tanah Untuk Pembangunan. Jakarta: Mimeo, 2010.

Bruggink, JJ. Rechtsrefleties. Alih Bahasa: Arif Sidharta, Bandung: PT.

Citra Aditya Bakti, 1999.

Gunanegara. "Pengadaan Tanah Oleh Negara untuk Kepentingan

Umum". Disertasi. Surabaya: Program Pascasarjana

Universitas Airlangga, 2006.

Hanbal (al-), Ahmad ibn. Musnad Ahmad. Hadis Nomor 3946.

Kaliannam, Maniam. et all. "Public Privat Partnership for E-

Government Servis: Lesson from Malaysia", International

Juornal of Institutions and Economies, Vol. 2. Nomor 2. Oktober. 2010.

Koeswahyono, Imam. "Suatu Catatan Kritis Atas Undang-Undang

Pengadaan Tanah Untuk Pembangunan Nomor 2 Tahun 2012".

Makalah, t.t. ."Melacak Dasar Konstitusional Pengadaan Tanah Untuk

Kepentingan Pembangunan Bagi Umum". Makalah, t.t.

Luth, Thohir. Syariat Islam Mengapa Takut. Malang: UB Press. 2011.

Muhadar. Korban Pembebasan Tanah Perspektif Viktimologi. Yogyakarta: Rangkang, 2013.

Musthofa \& Suratman. Penggunaan Hak Atas Tanah untuk Industri. Jakarta: Sinar Grafika, 2013.

Prasetyo, Irwan. "Kerjasama Pemerintah Swasta dalam Pembangunan Perkotaan". Buletin Tata Ruang. NovemberDesember, 2009.

Rifaii, Bachtiar. "Meninjau Kembali Kebijakan Kerjasama Pemerintah dan Swasta dalam Pembangunan Infrastruktur di 
Indonesia; Sebuah Perspektif Pekerjaan Rumah Bagi Indonesia", Ringkasan Laporan Penelitian, Jakarta: LIPI, 2011. Roosdiono. Undang-undang Nomor 2 tahun 2012". Makalah. tt. Sie Infokum, Sie. Kerjasama Pemerintah dengan Badan Usaha Swasta dalam penyediaan Infrastruktur. Jakarta: Ditama Binbangkum, tt. Sitorus, Olloan. \& Dayat Limbong. Pengadaan Tanah untuk Kepentingan Umum. Yogyakarta: Penerbit Mitra Kebijakan Tanah Indonesia, 2004.

Soemardjono, Maria SW. Kebijakan Pertanahan Antara Regulasi dan Implementasi. Jakarta: Penerbit Buku Kompas, 2005.

. "Anatomi UU No 2 Tahun 2012 tentang Pengadaan Tanah

bagi Pembangunan untuk Kepentingan Umum Tinjauan

Filosofis, Yuridis, dan Sosiologis", Makalah disampaikan pada Sosialisasi Undang-Undang Nomor 2 Tahun 2012, diselenggarakan oleh Direktorat Utama Bidang Pembinaan dan Pengembangan Hukum Pemeriksaan Keuangan RI, Jakarta, 22 Maret, 2012.

Sudjito, et al. Restorasi Kebijakan Pengadaan, Perolehan, Pelepasan dan

Pendayagunaan Tanah Serta Kepastian Hukum di Bidang Investasi.

Yogyarakta: Tugujogja Pustaka, 2012.

Susanto, Bambang. dan Muhammad Ali Berawi. "Perkembangan Kebijakan Pembiayaan Infrastruktur Transportasi Berbasis Kerjasama Pemerintah Swasta di Indonesia". Jurnal Transportasi. Vol. 12. Nomor 2 Agustus, 2012.

Sutedi, Adrian. Implementasi Prinsip Kepentingan Umum dalam Pengadaan Tanah Untuk Pembangunan. Jakarta: Sinar Grafika, 2008.

Utama, Dwinanta. "Prinsip dan Strategi Penerapan Public Private Partnership dalam Penyediaan Infrastruktur Transportasi", Jurnal Sain dan Teknologi Indonesia Vol. 12. Nomor 3 Desember, 2010.

Yamin, Muhammad. dan Abdul Rahim Lubis. Pencabutan Hak, Pembebasan, dan Pengadaan Tanah, Bandung: Mandar Maju, 2011. 
Yusriadi. Industrialisasi \& Perubahan Fungsi Sosial Hak Milik Atas Tanah. Yogyakarta: Genta Publising, 2010.

Zahrah, Abu. al-Milkiyyah wa al-Nadhriyyat al-'Aqd fi al-Syarî'ah alIslâmiyah. Mesir: Matba'ah Fathullah al-Yaas, t.t.

Zahrah, Muhammad Abu. al-Takâful al-Ijtimâ'iy. Kairo; Dar al-Fikr al-Arabi, tt.

Zarqa (al-), Mustofa Ahmad. al-Madkhal al-Figh al-'Amm. II, Matba'ah al-Jami'ah al-Suriyah.

Republik Indonesia. Undang-Undang tentang Pengadaan Tanah Untuk Kepentingan Umum. Undang-undang Nomor 2 Tahun 2012.

Republik Indonesia. Peraturan Presiden tentang Pengadaan Tanah Untuk Kepentingan Umum. Peraturan Presiden Nomor 65 Tahun 2006 jo Peraturan Presiden Nomor 36 Tahun 2005.

Republik Indonesia. Peraturan Presiden tentang Pelaksanaan Pengadaan Tanah Untuk Kepentingan Umum. Peraturan Presiden Nomor 71 tahun 2012.

Republik Indonesia. Keputusan Presiden tentang Pengadaan Tanah

Bagi Pembangunan untuk Kepentingan Umum. Keputusan Presiden Nomor 55 Tahun 1993.

Republik Indonesia. Peraturan Menteri Dalam Negeri tentang Acara

Pembebasan Tanah. Peraturan Menteri Dalam Negeri Nomor 15 Tahun 1975.

Republik Indonesia. Peraturan Menteri Dalam Negeri tentang Acara

Pembebasan Tanah untuk Kepentingan Swasta. Peraturan Menteri Dalam Negeri Nomor 2 Tahun 1976. 